\title{
Engineering Students' EFL Needs at the Tertiary Level of Education in Bangladesh: Expectations and Existence
}

\author{
Md. Habibur Rahman \\ Lecturer, Department of English, Bangladesh Army International University of Science and \\ Technology (BAIUST) \\ habibur@baiust.edu.bd \\ Md. Musrifur Jelane \\ Lecturer, Department of English, Begum Rokeya University, Rangpur \\ m.jelane@brur.ac.bd
}

DOI: http://doi.org/ 10.36892/ijlls.v3i2.542

\begin{tabular}{|c|c|}
\hline & Abstract \\
\hline 23/03/2021 & Conducting needs analysis is a prevalent phenomenon in designing curriculum \\
\hline $\begin{array}{l}\text { Accepted: } \\
\text { 22/05/2021 }\end{array}$ & $\begin{array}{l}\text { in language teaching and learning. This paper explored the English language } \\
\text { needs of engineering students at the tertiary level of education in Bangladesh } \\
\text { vis-à-vis four basic language skills. Moreover, this paper tried to shed some } \\
\text { light on the gaps between learners' present level of competence and target }\end{array}$ \\
\hline $\begin{array}{l}\text { Keywords: } \\
\text { needs analysis, } \\
\text { engineering, tertiary, } \\
\text { mixed approach, } \\
\text { language skills }\end{array}$ & $\begin{array}{l}\text { needs. This study followed the mixed approach (both quantitative approach and } \\
\text { qualitative approach) to collect data through questionnaires, semi-structured } \\
\text { interviews, and focus group discussions. Under the random stratified sampling } \\
\text { method, the study collected data from } 99 \text { undergraduate engineering students } \\
\text { and } 15 \text { EFL teachers from different universities in Bangladesh. The findings of } \\
\text { the study revealed that engineering students felt the ardent need for all the four } \\
\text { major language skills (listening, speaking, reading, and writing). The findings } \\
\text { also addressed the needs of the subskills regarding each language skill. } \\
\text { Additionally, the offered courses were not adequately addressing the language } \\
\text { needs of the students. Moreover, the duration and number of English language } \\
\text { classes were not sufficient to meet the needs of the engineering students. Based } \\
\text { on the findings, this study made some recommendations to minimize the gaps } \\
\text { between engineering students' present and target needs of the English } \\
\text { language. }\end{array}$ \\
\hline
\end{tabular}

\section{INTRODUCTION}

Needs analysis is fundamental for planning a sound educational program. In 1920s, the term 'analysis of needs' (as cited in West, 1994, p. 1) first appeared in India. Michael West introduced the concept and he mentioned two separate and conflicting concepts of 'need'; the first one is learners' foreign language need in target situation and the second one is learners' competence in target language at the time of training (West, 1994). Davis (1977) and Robinson (1991) took both learner's target needs and learner's present level of competence into consideration while conducting needs analysis. Moreover, Richard \& Rogers (1986) opines that needs analysis is concerned with ascertaining learners' general language needs, specific language needs, societal expectations, or specific needs. Lawrence et al. (1991) emphasized on the use of surveys to determine both general and specific problems experienced by a target group. Again, Brumfit \& Roberts (1987) emphasized on the effectiveness of needs analysis to determine suitable teaching techniques. Moreover, West (1994) studied different modes of 
needs analysis, namely Target-situation analysis, Deficiency analysis, Strategy analysis, Means analysis, their effectiveness, and constraints. Among the different modes of needs analysis, this study adopted Deficiency analysis to determine the language needs of undergraduate engineering students at the tertiary level of education in Bangladesh, which consider learners' present needs/wants and the requirements of the target needs. In addition, Allwright (1982) and Robinson (1991) titled this process as combined target-situation analysis and present-situation analysis.

Almost all the engineering departments in Bangladesh offer the English language course to their respective students in public and private universities. The general aim of these English courses is to develop the English language proficiency of the engineering students both in their academic and professional career (Rahman et al., 2017). However, the present English language courses offered to the engineering students at the tertiary level of education in Bangladesh are unable to fulfill the aim since the desired proficiency in English language of the engineering students is not good enough (Sultana, Sultana \& Zakaria, 2019). One of the main reasons for this problem is not to conduct a proper needs analysis before administrating these courses. Therefore, this study attempts to determine the English language needs of engineering students at the tertiary level of education in Bangladesh. The study encompassed the following objectives:

i) To identify students' perceptions of their needs and wants.

ii) To discover how students rated their competence in particular language skills (e.g., listening).

iii) To ascertain the language skills-based areas where they are facing problems.

iv) To determine the extent to which the student-perceived needs match those of their teachers-perceived needs.

With reference to the above-mentioned objectives, this study assessed the following questions:

i) What are the English Language needs of the engineering students at the tertiary level of education in Bangladesh with respect to reading, writing, listening, and speaking skills?

ii) What gaps do exist between target needs and present level of competence of the current engineering students at the tertiary level of education in Bangladesh based on their linguistic competence?

\section{LITERATURE REVIEW}

There is an avalanche of literature available related to the English language needs of the students of different disciplines. However, most of them covered the humanities, business studies, automotive studies and non-English major students. On the other hand, some studies regarding the English language needs of engineering students have been conducted abroad. Therefore, the literature on the English language needs of engineering students at tertiary level of education in Bangladesh is quite inadequate.

Qasemi and Ibrahim (2015), Gözüyeşil (2014), and Mohamed, et al.,(2014) conducted studies to examine the English language needs of engineering students. Although Qasemi \& Ibrahim (2015) and, Gözüyeşil (2014) tried to identify the English language needs of engineering undergraduates, Mohamed, et al., (2014) focused their studies on the English language needs of professional engineers at their workplace. The studies of Qasemi \& Ibrahim (2015), Gözüyeşil (2014), and Mohamed, et al., (2014) revealed that the English language course for the engineering graduates had a significant importance on their academic as well as professional career. Qasemi and Ibrahim (2015) recommended to modifying the existing syllabus according to engineering students' needs. On the other hand, Gözüyeşil (2014) 
suggested to give more importance to the speaking and reading skills of the engineering students. However, Mohamed, et al., (2014) made recommendations to focus more on soft skills to the engineering graduates and introduce the ESP programs to align the diverse language needs of the different disciplines.

Jamilah (2018), Lestari, et al., (2017), Mognhode and Woldemariam (2015), and Talif and Noor (2009) examined the English learning needs of non-English major students at the tertiary level of education. Mognhode and Woldemariam (2015) identified the English language needs of business studies students while Lestari, Syahrial, \& Suwarno (2017) explored the needs of the language skills, sub skills and vocabularies for the engineering disciplines. However, both the studies of Mognhode and Woldemariam (2015), and Lestari, Syahrial, \& Suwarno (2017) found that a gap existed between present needs and target needs of the non-English major students. On the other hand, Jamilah (2018), and Talif \& Noor (2009) identified that students needed particular language skills which would develop their language competency in the workplace. Jamilah (2018), and Talif and Noor (2009) recommended that the contact hours needed to increase and more challenging language activities were required to develop the language proficiency of the non-English major students. However, Mognhode and Woldemariam (2015), and Lestari, et al., (2017) suggested to give more emphasis on learning the technical vocabularies and integrated learning of the four English language skills.

Sultana et al (2019), Chaudhury (2010), and Sudha (2017) conducted studies on the English language needs of the non-English major students at the tertiary level of education in Bangladesh. Although Sudha (2017) examined the effectiveness of English language courses for Non-English major students at the tertiary level of education in Bangladesh, Chaudhury (2010) tried to identify, particularly, the needs regarding English language learning of the students of arts and humanities at the tertiary level of education in Bangladesh. Both of these studies found that the present English language courses were not fulfilling all the necessary needs that the non-English major students need for their academic and professional success. Chaudhury (2010) suggested some changes in teaching styles for the effectiveness of the English language courses offered to the non-English major students. However, Sudha (2017) emphasized on the up-to-date syllabus and an increase of the classroom facilities.

On the other hand, Sultana, et al., (2019) conducted a study on Diploma level engineering students in Bangladesh. This study found that the present ESP syllabus was not adequate enough to meet the needs of the engineering students. Additionally, the number and duration of the English language courses were very limited. The study suggested updating the ESP syllabus according to learners' needs, giving more focus on functional aspects of the language, adopting various instructional methods, and increasing the number and duration of the language classes.

To sum up, there are discussions on the effectiveness of English language course for the non-English major students (Sultana et al, 2019, Sudha, 2017, and Chaudhury, 2009), the communication needs of the professional engineers (Mohamed et al, 2014), needs of language skills and sub-skills for the automotive students (Lestari et al, 2017), business studies (Mognhode and Woldemariam, 2015), and industry-linkage programs (Talif \& Noor, 2009). However, there is no specific research on English language needs of the engineering students at the tertiary level of education in Bangladesh. Therefore, there remains a research gap in this field. The purpose of this study is to fill in the gap with a critical approach.

\section{METHODOLOGY}

\subsection{RESEARCH DESIGN}

This research employed mixed-methods approach i.e., a combination of qualitative and quantitative studies. Creswell et al. (2008) presented five typical research types of mixedmethods study namely triangulation model, concurrent embedded design, explanatory design, 
exploratory design and sequential embedded design. This research adopted triangulation model. This model collects two sets of data simultaneously and uses them to understand the research questions thoroughly (Mackey \& Gass, 2015).

\subsection{POPULATION AND SAMPLING}

The target population of the study were the engineering students at the tertiary level of education in different public and private universities of Bangladesh. In addition, instructors who are active in teaching English to the engineering students at the tertiary level in Bangladesh also took part in this research. This study employed stratified random sampling (Brown, 1988) as a sampling method. Therefore, the engineering students at the tertiary level of education in different public and private universities of Bangladesh were divided into subgroups or strata based on their departments like Electrical and Electronic Engineering, Computer Science and Engineering, Civil Engineering, Mechanical Engineering, etc. Samples were then selected randomly from each subgroup or stratum. Under this stratified random sampling method, the sample size includes 99 engineering students and 15 instructors of tertiary level of education in Bangladesh.

\subsection{DATA COLLECTION}

Quantitative data were collected from 99 engineering students and 15 instructors of tertiary level of education in Bangladesh through questionnaires. The questionnaires used fivepoint Likert scale to measure the responses (Likert, 1932). A review of literature was carried out in order to design the research questionnaires. The questionnaire items were partly adapted from Chaudhury (2009) and from Gravatt et al. (1997). Separate questionnaires were designed to collect data from the students as well as from the instructors. On the other hand, qualitative data were collected through Interviews and Focus Group Discussion (FGD) reports. Five English teachers who had conducted the English classes to the engineering students were interviewed and a focus group discussion was carried out with 30 students in three groups where each group consisted of 10 students.

\subsection{DATA ANALYSIS}

Quantitative data were analyzed by using IBM SPSS Statistics. The statistical measurements used were mode, median, mean, and standard deviation to analyze and interpret the collected data. The statements assessing the expected responses of the participants were adopted through a five-point Likert scale (Likert, 1932). On the scale, the positively worded items were scored e.g., "Always"= 5, "Often"= 4, "Sometimes"= 3, "Rarely"=2, "Never"= 1 . However, the negatively worded items which address the opposite of the target concept were scored reversed before analysis i.e., 5 becomes 1,4 becomes 2 , etc.

\section{RESULTS AND FINDINGS}

This study employed descriptive statistics (e.g., mode, median, mean) to analyze and interpret data. In addition, this study used mean as a measure of central tendency and standard deviation (i.e., the measures of dispersion) to give more credibility to data analysis and interpretation.

\subsection{RESULTS OF THE STUDENTS' DATA:}

Table-1:

Students' frequency of need of the four language skills during their course of study

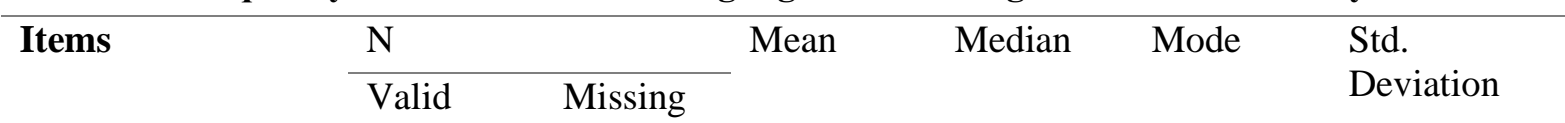




\begin{tabular}{lllllll}
\hline Listening & 99 & 0 & 4.2525 & 5 & 5 & 0.91856 \\
\hline Speaking & 99 & 0 & 3.8283 & 4 & 4 & 0.96933 \\
\hline Reading & 99 & 0 & 4.2828 & 5 & 5 & 0.93722 \\
\hline Writing & 99 & 0 & 4.1111 & 4 & 5 & 0.91349 \\
\hline
\end{tabular}

The results in Table- 1 show that among the four language skills, reading skill has the highest mean (4.2828) while speaking skill has the lowest mean (3.8283). The results indicate that students need the reading skill most frequently, whereas the frequency of need of the speaking skill is the least. However, mode and median scores indicate their needs regarding the basic language skills.

Table-2:

Students' frequency of facing difficulty in each of the four language skills during their course of study

\begin{tabular}{lllllll}
\hline Items & $\mathrm{N}$ & \multicolumn{2}{c}{ Mean } & Median & Mode & $\begin{array}{l}\text { Std. } \\
\text { Deviation }\end{array}$ \\
\cline { 2 - 3 } Listening & Valid & Missing & & & & 0.92381 \\
\hline Speaking & 99 & 0 & 3.0606 & 3 & 3 & 1.01838 \\
\hline Reading & 99 & 0 & 3.6061 & 4 & 3 & 1.04368 \\
\hline Writing & 99 & 0 & 2.9495 & 3 & 3 & 0.93325 \\
\hline
\end{tabular}

The results in Table- 2 show that among the four language skills, speaking skill has the highest mean (3.6061) while reading skill has the lowest mean (2.9495). The results reveal that students face most difficulty in speaking, whereas they face least difficulty in reading. However, mode and median score also indicates they are facing problems in other language skills as well.

Table-3:

\begin{tabular}{|c|c|c|c|c|c|c|}
\hline \multicolumn{7}{|c|}{ Students' frequency of facing problems with regard to English listening skills } \\
\hline \multirow[t]{2}{*}{ Items } & \multicolumn{2}{|l|}{$\mathrm{N}$} & \multirow[t]{2}{*}{ Mean } & \multirow[t]{2}{*}{ Median } & \multirow[t]{2}{*}{ Mode } & \multirow{2}{*}{$\begin{array}{l}\text { Std. } \\
\text { Deviation }\end{array}$} \\
\hline & Valid & Missing & & & & \\
\hline $\begin{array}{l}\text { Have trouble understanding } \\
\text { lectures. }\end{array}$ & 99 & 0 & 2.9697 & 3 & 3 & 1.08284 \\
\hline $\begin{array}{l}\text { Have trouble taking effective } \\
\text { notes. }\end{array}$ & 99 & 0 & 3.0101 & 3 & 3 & 0.99483 \\
\hline $\begin{array}{l}\text { Have to ask questions for } \\
\text { clarification to comprehend the } \\
\text { lecture. }\end{array}$ & 99 & 0 & 3.1515 & 3 & 3 & 0.94073 \\
\hline $\begin{array}{l}\text { Have difficulty understanding } \\
\text { lengthy descriptions. }\end{array}$ & 99 & 0 & 3.2222 & 3 & 3 & 1.03565 \\
\hline $\begin{array}{l}\text { Have trouble understanding } \\
\text { spoken instructions. }\end{array}$ & 99 & 0 & 3.0303 & 3 & 3 & 1.09222 \\
\hline $\begin{array}{l}\text { Have trouble understanding } \\
\text { informal language. }\end{array}$ & 99 & 0 & 3.0909 & 3 & 3 & 1.12568 \\
\hline $\begin{array}{l}\text { Have difficulty understanding } \\
\text { the subject matter of a talk. }\end{array}$ & 99 & 0 & 3.0202 & 3 & 3 & 1.07836 \\
\hline
\end{tabular}

The results in Table-3 show that among the problems regarding English listening skills, 'have difficulty understanding lengthy descriptions' has the highest mean (3.2222) while 'have trouble understanding lectures' has the lowest mean (2.9697). The results express that the students face most trouble in understanding lengthy descriptions, whereas they face least 
trouble

in

understanding

class

lectures.

Table-4:

Students' frequency of facing problems with regard to English speaking skills

\begin{tabular}{lllllll}
\hline Items & $\mathrm{N}$ & \multicolumn{2}{c}{ Mean } & Median & Mode & $\begin{array}{l}\text { Std. } \\
\text { Deviation }\end{array}$ \\
\cline { 2 - 3 } & Valid & Missing & & & & \\
\hline $\begin{array}{l}\text { Have difficulty in giving oral } \\
\text { presentation. }\end{array}$ & 99 & 0 & 3.6667 & 4 & 4 & 0.97938 \\
$\begin{array}{l}\text { Have trouble wording when you } \\
\text { say something quickly. }\end{array}$ & 99 & 0 & 3.6465 & 4 & 3 & 1.01331 \\
\hline $\begin{array}{l}\text { Worry about saying something in } \\
\text { English if you make a mistake. }\end{array}$ & 99 & 0 & 3.6566 & 4 & 4 & 0.99141 \\
\hline $\begin{array}{l}\text { Do not know how to express } \\
\text { something in English. }\end{array}$ & 99 & 0 & 3.0303 & 3 & 3 & 1.10153 \\
\hline $\begin{array}{l}\text { Do not know the best way to } \\
\text { express something in English. }\end{array}$ & 99 & 0 & 3.2323 & 3 & 3 & 0.90157 \\
\hline $\begin{array}{l}\text { Face trouble in pronunciation of } \\
\text { words. }\end{array}$ & 99 & 0 & 3.1818 & 3 & 3 & 1.01382 \\
\hline $\begin{array}{l}\text { Find it challenging to enter } \\
\text { discussion. }\end{array}$ & 99 & 0 & 3.2525 & 3 & 3 & 1.05311 \\
\hline
\end{tabular}

The result in Table-4 show that among the problems regarding English speaking skills, 'have difficulty in giving oral presentation' has the highest mean (3.6667) while 'do not know how to express something in English' has the lowest mean (3.0303). The results reveal that students face most difficulty in giving oral presentation, whereas they face less problem to say something in English.

Table-5:

Students' frequency of facing problems with regard to English reading skills

\begin{tabular}{|c|c|c|c|c|c|c|}
\hline \multirow[t]{2}{*}{ Items } & \multicolumn{2}{|l|}{$\mathrm{N}$} & \multirow[t]{2}{*}{ Mean } & \multirow[t]{2}{*}{ Median } & \multirow[t]{2}{*}{ Mode } & \multirow{2}{*}{$\begin{array}{l}\text { Std. } \\
\text { Deviation }\end{array}$} \\
\hline & Valid & Missing & & & & \\
\hline $\begin{array}{l}\text { Understanding the main } \\
\text { point of texts. }\end{array}$ & 99 & 0 & 3.5859 & 4 & 4 & 1.05955 \\
\hline $\begin{array}{l}\text { Reading a text quickly in } \\
\text { order to understand the } \\
\text { general idea of the content } \\
\text { (skimming). }\end{array}$ & 99 & 0 & 3.6061 & 4 & 4 & 0.95638 \\
\hline $\begin{array}{l}\text { Reading a text thoroughly in } \\
\text { order to comprehend the ins } \\
\text { and outs of the text. }\end{array}$ & 99 & 0 & 3.7778 & 4 & $4.00 \mathrm{a}$ & 1.03565 \\
\hline $\begin{array}{l}\text { Reading a text quickly in } \\
\text { order to find specific } \\
\text { information (scanning). }\end{array}$ & 99 & 0 & 3.5657 & 4 & 3 & 1.02182 \\
\hline $\begin{array}{l}\text { Inferring the meaning of } \\
\text { unknown words in a text. }\end{array}$ & 99 & 0 & 3.5455 & 4 & 4 & 0.99255 \\
\hline $\begin{array}{l}\text { Interpreting a writer's } \\
\text { attitude and purpose. }\end{array}$ & 99 & 0 & 3.4848 & 4 & $3.00 \mathrm{a}$ & 0.91878 \\
\hline $\begin{array}{l}\text { Reading to take part in } \\
\text { critical discussion. }\end{array}$ & 99 & 0 & 3.5051 & 4 & 4 & 1.07261 \\
\hline
\end{tabular}

The results in Table-5 show that among the problems regarding English reading skills, 'reading a text thoroughly in order to comprehend the ins and outs of the text' has the highest mean (3.7778) while 'interpreting a writer's attitude and purpose' has the lowest mean (3.4848). The results express that the students face most difficulty in reading a text thoroughly to 
understand the ins and outs of the text, whereas they face least difficulty to understand writer's attitude and purpose.

Table-6:

Students' frequency of facing problems with regard to English writing skills

\begin{tabular}{|c|c|c|c|c|c|c|}
\hline \multirow[t]{2}{*}{ Items } & \multicolumn{2}{|l|}{$\mathrm{N}$} & \multirow[t]{2}{*}{ Mean } & \multirow[t]{2}{*}{ Median } & \multirow[t]{2}{*}{ Mode } & \multirow[t]{2}{*}{ Std. Deviation } \\
\hline & Valid & Missing & & & & \\
\hline $\begin{array}{l}\text { Using correct punctuation and } \\
\text { spelling. }\end{array}$ & 99 & 0 & 3.7374 & 4 & 4 & 0.94314 \\
\hline Structuring sentences. & 99 & 0 & 3.7677 & 4 & 4 & 0.92393 \\
\hline $\begin{array}{ll}\text { Using } & \text { appropriate } \\
\text { vocabulary. } & \end{array}$ & 99 & 0 & 3.7475 & 4 & 4 & 0.87299 \\
\hline Organizing paragraphs. & 99 & 0 & 3.5657 & 4 & 4 & 1.00165 \\
\hline $\begin{array}{l}\text { Expressing what you want to } \\
\text { say clearly. }\end{array}$ & 99 & 0 & 3.7879 & 4 & 4 & 1.02293 \\
\hline $\begin{array}{l}\text { Evaluating and revising your } \\
\text { writing. }\end{array}$ & 99 & 0 & 3.5758 & 4 & 4 & 1.07941 \\
\hline $\begin{array}{l}\text { Completing written tasks in } \\
\text { time. (e.g., exams, tests, etc.) }\end{array}$ & 99 & 0 & 3.8081 & 4 & 4 & 1.08493 \\
\hline
\end{tabular}

The results in Table-6 show that among the problems regarding English writing skills, 'Completing written tasks in time, e.g., exams, tests, etc.' has the highest mean (3.8081) while the 'Organizing paragraphs' has the lowest mean (3.5657). The results reveal that students face most difficulty in completing written tasks within the time available, whereas they face least difficulty to organize paragraphs.

\subsection{RESULTS OF THE INSTRUCTORS' DATA:}

Table-7:

Instructors' perception on students' frequency of facing problems with regard to English listening skills

\begin{tabular}{|c|c|c|c|c|c|c|}
\hline \multirow[t]{2}{*}{ Items } & \multicolumn{2}{|l|}{$\mathrm{N}$} & \multirow[t]{2}{*}{ Mean } & \multirow[t]{2}{*}{ Median } & \multirow[t]{2}{*}{ Mode } & \multirow{2}{*}{$\begin{array}{l}\text { Std. } \\
\text { Deviation }\end{array}$} \\
\hline & Valid & Missing & & & & \\
\hline $\begin{array}{l}\text { Have trouble understanding } \\
\text { lectures. }\end{array}$ & 15 & 0 & 3.6 & 4 & 4 & 0.50709 \\
\hline $\begin{array}{l}\text { Have trouble taking effective } \\
\text { notes. }\end{array}$ & 15 & 0 & 3.2 & 3 & 3 & 0.67612 \\
\hline $\begin{array}{l}\text { Have to ask questions for } \\
\text { clarification to comprehend the } \\
\text { lecture. }\end{array}$ & 15 & 0 & 3.8 & 4 & 4 & 0.86189 \\
\hline $\begin{array}{l}\text { Have difficulty understanding } \\
\text { lengthy descriptions. }\end{array}$ & 15 & 0 & 3.4667 & 3 & 3 & 0.91548 \\
\hline $\begin{array}{l}\text { Have trouble understanding } \\
\text { spoken instructions. }\end{array}$ & 15 & 0 & 2.9333 & 3 & 3 & 0.88372 \\
\hline $\begin{array}{l}\text { Have trouble understanding } \\
\text { informal language. }\end{array}$ & 15 & 0 & 2.8667 & 3 & 3 & 0.83381 \\
\hline Have difficulty understanding & 15 & 0 & 3 & 3 & 3 & 0.65465 \\
\hline
\end{tabular}

the subject matter of a talk.

The results in Table-7 show that among the problems regarding students' English listening skills, 'have to ask questions for clarification to comprehend the lecture' has the highest mean (3.8) while 'have difficulty understanding the subject matter of a talk' has the lowest mean (3). The results reveal that, according to instructors' perception, students face 
frequent problem regarding listening skill, whereas students face least difficulty in understanding the subject matter of a talk.

Table-8:

Instructors' perception on students' frequency of facing problems with regard to English speaking skills

\begin{tabular}{|c|c|c|c|c|c|c|}
\hline \multirow[t]{2}{*}{ Items } & \multicolumn{2}{|l|}{$\mathrm{N}$} & \multirow[t]{2}{*}{ Mean } & \multirow[t]{2}{*}{ Median } & \multirow[t]{2}{*}{ Mode } & \multirow{2}{*}{$\begin{array}{l}\text { Std. } \\
\text { Deviation }\end{array}$} \\
\hline & Valid & Missing & & & & \\
\hline $\begin{array}{l}\text { Have difficulty } \\
\text { presentation. }\end{array}$ & 15 & 0 & 4.1333 & 4 & 4 & 0.74322 \\
\hline $\begin{array}{l}\text { Have trouble wording when you say } \\
\text { something quickly. }\end{array}$ & 15 & 0 & 3.8667 & 4 & 4 & 0.63994 \\
\hline $\begin{array}{l}\text { Worry about saying something in } \\
\text { English if you make a mistake. }\end{array}$ & 15 & 0 & 4.1333 & 4 & 4 & 0.83381 \\
\hline $\begin{array}{l}\text { Do not know how to express } \\
\text { something in English. }\end{array}$ & 15 & 0 & 3 & 3 & 3 & 0.65465 \\
\hline $\begin{array}{l}\text { Do not know the best way to express } \\
\text { something in English. }\end{array}$ & 15 & 0 & 3.5333 & 3 & 3 & 0.63994 \\
\hline $\begin{array}{l}\text { Face trouble in pronunciation of } \\
\text { words. }\end{array}$ & 15 & 0 & 3.8667 & 4 & 4 & 0.74322 \\
\hline $\begin{array}{l}\text { Find it challenging to enter } \\
\text { discussion. }\end{array}$ & 15 & 0 & 3.4667 & 3 & 3 & 0.63994 \\
\hline
\end{tabular}

The results in Table-8 show that among the problems regarding students' English speaking skills, 'have difficulty giving oral presentation' and 'worry about saying something in English if you make a mistake' both have the highest mean (4.1333) while 'do not know how to express something in English' has the lowest mean (3). The results indicate that, according to instructors' perception, students face most problems to give oral presentation and to express something in English if they make a mistake, whereas they face less problem in proper wording to express something in English.

Table-9:

Instructors' perception on students' frequency of facing problems with regard to English reading skills

\begin{tabular}{lllllll}
\hline Items & $\mathrm{N}$ & & Mean & Median & Mode & Std. Deviation \\
\cline { 2 - 7 } & Valid & Missing & & & & \\
\hline Understanding the main point of texts. & 15 & 0 & 2.9333 & 3 & 3 & 0.59362 \\
\hline $\begin{array}{l}\text { Reading a text quickly in order to } \\
\text { understand the general idea of the } \\
\text { content (skimming). }\end{array}$ & & 0 & 3.2 & 3 & 3 & 0.56061 \\
$\begin{array}{l}\text { Reading a text thoroughly in order to } \\
\text { comprehend the ins and outs of the text. }\end{array}$ & 15 & 0 & 3.1333 & 3 & 3 & 0.74322 \\
\hline $\begin{array}{l}\text { Reading a text quickly in order to find } \\
\text { specific information (scanning). }\end{array}$ & 15 & 0 & 3.2667 & 3 & 3 & 0.70373 \\
\hline $\begin{array}{l}\text { Inferring the meaning of unknown } \\
\text { words in a text. }\end{array}$ & 15 & 0 & 3.3333 & 3 & 3 & 0.61721 \\
\hline $\begin{array}{l}\text { Interpreting a writer's attitude and } \\
\text { purpose. }\end{array}$ & 15 & 0 & 3.6667 & 3 & 3 & 0.8165 \\
\hline $\begin{array}{l}\text { Reading to take part in critical } \\
\text { discussion. }\end{array}$ & 15 & 0 & 3.8 & 4 & 4 & 0.67612 \\
\hline
\end{tabular}

The results in Table-9 show that among the problems regarding students' English reading skills, 'reading to take part in critical discussion' has the highest mean (3.8) while 'understanding the main point of texts' has the lowest mean (2.9333). The results reveal that, 
according to instructors' perception, students face difficulty in reading a text in order to respond critically, whereas they face less difficulty in understanding the main point of texts.

Table-10:

Instructors' perception on students' frequency of facing problems with regard to English writing skills

\begin{tabular}{lllllll}
\hline Items & $\mathrm{N}$ & & Mean & Median & Mode & Std. Deviation \\
\cline { 2 - 7 } & Valid & Missing & & & & \\
\hline $\begin{array}{l}\text { Using correct punctuation } \\
\text { and spelling. }\end{array}$ & 15 & 0 & 3.6667 & 4 & 3 & 0.72375 \\
\hline $\begin{array}{l}\text { Structuring sentences. } \\
\text { Using appropriate }\end{array}$ & 15 & 0 & 3.6667 & 4 & 3 & 0.72375 \\
\hline $\begin{array}{l}\text { vocabulary. } \\
\text { Organizing paragraphs. }\end{array}$ & 15 & 0 & 3.5333 & 4 & 4 & 0.63994 \\
\hline $\begin{array}{l}\text { Expressing what they want } \\
\text { to say clearly. }\end{array}$ & 15 & 0 & 3.2 & 3 & 3 & 0.67612 \\
\hline $\begin{array}{l}\text { Evaluating and revising } \\
\text { their own writing. }\end{array}$ & 15 & 0 & 3.6 & 4 & $3.00 \mathrm{a}$ & 0.98561 \\
\hline $\begin{array}{l}\text { Completing written tasks in } \\
\text { time. (e.g., exams, tests, etc.) }\end{array}$ & 15 & 0 & 3.2 & 3 & 3 & 0.7746 \\
\hline
\end{tabular}

a. Multiple modes exist. The smallest value is shown.

The results in Table-10 show that among the problems regarding students' English writing skills, 'using correct punctuation and spelling' and 'structuring sentences' both have the highest mean (3.6667) while 'organizing paragraphs' and 'completing written tasks in time. (e.g., exams, tests, etc.)' both have the lowest mean (3.2). The results express that, according to instructors' perception, students face most problems using correct punctuation and spelling and structure sentences where students face least problems to organize paragraphs and complete written tasks in time.

\section{DISCUSSION ON THE FINDINGS}

The results and discussion of the data mentioned above are all related to the research questions. There are two research questions of this paper. The first research question is "What are the English Language needs of the undergraduate engineering students at the tertiary level of education in Bangladesh with respect to reading, writing, listening, and speaking skills?" The study revealed the language needs by identifying the problems (see, Table-3,4,5,6) they are facing in the four skills which clearly indicates their lack of mastery of the four skills in general and the items in Table-3,4,5 \& 6 mentioned under the major skills to be specific. The Focus group discussion also revealed students' incompetence regarding English due to several reasons: firstly, they spend very less or no time in learning skills as they are more focused and motivated in learning engineering subjects rather studying English; secondly, they were asked how much time they spent in learning English in a week and the findings shows they spend less time in leaning EFL courses in comparison to other engineering courses; thirdly, they were asked about the language learning materials and also asked whether they feel motivated to study the materials and the findings reveal their lack of motivation; and finally, they were asked how much the offered language course fill in their language need, and the findings show mixed responses and if we summarize their opinions we can say that it's not fulfilling the language needs and this claim is also supported by the data that were collected from 99 students. Moreover, this finding is also supported by the study of Sultana et al. (2019) which also reported that the present EAP syllabus was not adequate enough to meet the language needs of the engineering students. In addition, in this research we tried to incorporate instructors' 
responses to bring a clear picture of existing situation of language teaching and learning (see, Table-11, 12, 13, 14) at the tertiary level of education in Bangladesh.

The second research question is "What gaps do exist between target needs and present level of competence of the current engineering students at the tertiary level of education in Bangladesh based on their linguistic competence?" The study revealed that target needs are not adequately addressed by the syllabus. The interview of five academics revealed that the students were far behind to attain communicative competence (see, Table-11, 12, 13, 14). The 'gap' is not recognizing their language needs as syllabi don't reflect learners' language need and this finding is supported by Gözüyeşil (2014) which reported that the present curriculum of English for the Engineering students needed to update according to the needs of the students and recommendations of the teachers.

\section{CONCLUSION AND RECOMMENDATIONS}

Needs analysis in language teaching and learning is important for manifold reasons. Particularly, it helps to discover what language skills are necessary to carry out a specific role, decide whether an existing course satisfactorily addresses the requirements of potential students, diagnose what students able to do as well as what they need to be able to do and gather information of particular problems learners are experiencing. Therefore, conducting needs analysis is basic for designing a sound educational program. The present study is designed to determine engineering students' English language needs at the tertiary level of education in Bangladesh. This study explores that the students are not sufficiently skilled to fulfill the target language needs since the present course design does not adequately address the language needs of the students from engineering disciplines. Moreover, a gap exists between present situation and target needs of learners. This paper tries to reveal the gap between learners' present level of competence and target needs.

Based on the findings, some recommendations might be made in order to minimize the gap between present and target needs of engineering students regarding English language. Firstly, the present English language syllabus of engineering disciplines at the tertiary level of education in Bangladesh needs to update and modify according to learners' needs. Additionally, the recommendations of the English language teachers for respective engineering disciplines should be included while designing the syllabus. Moreover, both functional aspects and notional aspects of language need to be incorporated while designing the English language syllabus for the engineering students.

Secondly, the present duration of the English language course (which is 4 to 6 months depending on the universities) for the students of engineering disciplines is not enough to meet the demands of the English language needs. Moreover, the number of English classes offered to the engineering students in one semester is inadequate to fulfill the needs of the students. Therefore, both number and duration of the English language courses for the engineering students need to increase.

Thirdly, the findings of this study show that among the four language skills (listening, speaking, reading and writing) engineering students face most difficulty in speaking. Particularly, students face most difficulty in giving oral presentation. Besides, understanding lengthy descriptions and comprehending the details of a text through careful reading are the most difficult areas regarding listening, reading and writing skills of the engineering students. Therefore, more focus should be given on the development of the presentation skills. Nonetheless, interactive class discussion, giving more importance to skimming, scanning, predicting, inferring and practicing more writing tasks within time limit during the class can be a good practice to develop listening, reading and writing skills of the engineering students.

Fourthly, modern and interactive classroom teaching techniques could be incorporated to eliminate the difficulties engineering students face regarding the listening, speaking, reading and writing. For example, information gap, role paly, simulations, jigsaw activities, peer 
conversation, group debate, word mapping, quick writing, etc. could be used to make the learning more effective and interactive. Moreover, English language teachers should explore and use the classroom techniques which would be suitable for the development of English language skills of the engineering students.

Fifthly, needs analysis is a systematic and continuous process. Needs analysis may be conducted before, amid and after the language program (Richards, 2001). Most of the cases, we find that needs analysis is not carried out during the course and at the end of the course. However, all the three phases (before, amid and after) of needs analysis should be given equal importance to fill in the gap of the learners' present and target needs.

Last but not the least, incorporating challenging language learning activities, motivating students, creating learner-centered classroom, upgrading classroom facilities and resources for practice could be helpful to fulfill the English language needs of the engineering students.

\section{REFERENCES}

Allwright, R. (1982). Perceiving and pursuing learner's needs. In M. Geddes \& Sturtridge (eds.), Individualisation, 24-31. Oxford: Modern English Publications.

Brown, J. D. (1988). Understanding research in second language learning: A teacher's guide to statistics and research design. Cambridge University Press.

Brumfit, C.J. \& Roberts, J.T. (1987). An Introduction to language and language learning with comprehensive glossary of terms. London: Batsfords Academic and Education.

Chaudhury, T. A. (2009). Identifying the English language needs of humanities students at Dhaka University. The Dhaka University Journal of Linguistics, 2(4), 59-91. https://doi.org/10.3329/dujl.v2i4.6900

Creswell, J. W., Plano Clark, V. L., \& Garret, A.L. (2008). Methodological issues in conducting mixed methods research designs. In M. Bergman (Ed.), Advances in mixed method research (pp. 66-84). London: Sage.

Davis, A. (1997). Do foreign students have problems? In Cowie \& Heathon (eds.), 34-6.

Gözüyeşil, E. (2014, February). An analysis of engineering students' English language needs. Procedia - Social and Behavioral Sciences, 4182-4186. https://doi.org/10.1016/j.sbspro.2014.01.913

Gravatt, B. D., Richards, J. C., \& Lewis, M. N. (1997). Language needs in tertiary studies: ESL students at the University of Auckland. University of Auckland, Institute of Language Teaching and Learning.

Jamilah, J. (2018). English learning needs of non-English major students of higher education. doi: 10.13140/RG.2.2.21852.90243

Lawrence, R.F., Carle, H.B., Paul, G.F., \& Gary, L.K. (1991). Investigation communication: An introduction to research method. Jersey city: Prentice Hall, Inc.

Lestari, S., Syahrial, \& Suwarno, B. (2017). Language skills, sub-skills and vocabularies needed by automotive department students of technical high school: A need analysis study. Journal of Applied Linguistics and Literature, 2(2).

Likert, R. (1932). A technique for the measurement of attitudes. Archives of psychology. 
Mackey, A., \& Gass, S. M. (2015). Second language research: Methodology and design. Routledge.

Mognhode, T., \& Woldemariam, H. Z. (2015). The English language needs of business students at Adama Science and Technology University, Ethiopia. Nawa Journal of Language and Communication, 9(1).

Mohamed, A. A., Radzuan, N. R. M., Kassim, H., \& Ali, M. M. A. (2014). Conceptualizing English workplace communication needs of professional engineers: the challenges for English language tertiary educators. International Journal of Contemporary Business Management 1(1), 1-9.

Qasemi, A. S. \& Ibrahim, A. H. (2015). An investigation of English language needs of engineering undergraduates at Jawzjan University. In D. M. S. Sahibi, D. M. S. Yusop, F. F. M. Ali, S. Ismail, \& M. I. A. Wahab (Eds.). 1st International Conference on Language, Education \& Innovation (pp. 64-70). Kuala Lumpur, Malaysia. Interdisciplinary Circle of Science, Arts and Innovation.

Rahman, M., Hussain, N., \& Uddin, K. (2017). Evaluating English language courses of engineering universities in Bangladesh: Insiders' perceptions. NAEM Journal, 12(24), 113-123.

Richard, J.C. \& Rogers, T.S. (1986). Approaches and Methods in language teaching. Cambridge: Cambridge University Press.

Richards, J. C. (2001). Curriculum development in language teaching. Cambridge: Cambridge University Press.

Robinson, P. (1991). ESP today. Hemel Hempstead: Prentice Hall International.

Sudha, M. M. (2017). The effectiveness of English language courses as EFL in undergraduate level at Jahangirnagar University. International Journal of English Language Teaching 5(8), 7-26.

Sultana, F., Sultana, N., \& Zakaria, D. A. (2019). An evaluation of fundamental English courses: A scrutiny of their effectiveness at an engineering university, Bangladesh. International Journal of English and Literature (IJEL), 9(3), 47-62.

Talif, R., \& Noor, R. (2009). Connecting language needs in the workplace to the learning of English at tertiary level. Pertanika Journal of Social Science \& Humanities, 17(2), 6577.

West, R. (1994). Needs analysis in language teaching. Language Teaching, 27(01), pp 1-19 doi:10.1017/s0261444800007527

\section{$\underline{\text { AUTHORS' BIO }}$}

Md. Habibur Rahman is a Lecturer at the Department of English, Bangladesh Army International University of Science and Technology (BAIUST), Cumilla Cantonment, Cumilla. He completed his MA in Applied Linguistics and ELT and BA (Hons.) in English from the Department of English, Jahangirnagar University. His research interests include 
curriculum development, ESL/EFL acquisition/learning, technology in education, language teaching methodologies and stylistics.

Md. Musrifur Jelane is a Lecturer at the Department of English, Begum Rokeya University, Rangpur (BRUR). He completed his MA in Applied Linguistics and ELT and $B A$ (Hons.) in English from the Department of English, Jahangirnagar University. His areas of interests inresearch include EFL/ESL syllabus design, curriculum development, language teaching methodologies and post method pedagogy. 